\title{
Effect of different levels of rapidly degradable carbohydrates calculated by a simple rumen model on performance of lactating dairy cows
}

\author{
J. Doorenbos, ${ }^{* 1}$ J. Martín-Tereso, ${ }^{*}$ J. Dijkstra, $†$ and H. van Laar* \\ *Trouw Nutrition R\&D, PO Box 220, 5830 AE Boxmeer, the Netherlands \\ †Animal Nutrition Group, Wageningen University and Research, PO Box 338, 6700 AH Wageningen, the Netherlands
}

\begin{abstract}
Aggregating rumen degradation characteristics of different carbohydrate components into the term modeled rapidly degradable carbohydrates (mRDC) can simplify diet formulation by accounting for differences in rate and extent of carbohydrate degradation within and between feedstuffs. This study sought to evaluate responses of lactating dairy cows to diets formulated with increasing levels of mRDC, keeping the supply of other nutrients as constant as possible. The mRDC content of feedstuffs was calculated based on a simple rumen model including soluble, washable, and nonwashable but potentially degradable fractions, as well as the fractional degradation and passage rates, of sugar, starch, neutral detergent fiber, and other carbohydrates. The mRDC term effectively represents the total amount of carbohydrates degraded in the rumen within $2 \mathrm{~h}$ after ingestion. Fifty-two lactating Holstein cows (of which 4 were rumen fistulated) were assigned to 4 treatments in a $4 \times 4$ Latin square design. Treatments were fed as a total mixed ration consisting of $25.4 \%$ corn silage, $23.1 \%$ grass silage, $11.6 \%$ grass hay, and $39.9 \%$ concentrate on a dry matter basis. Differences in $\mathrm{mRDC}$ were created by exchanging nonforage neutral detergent fiber-rich ingredients (mainly sugar beet pulp) with starch-rich ingredients (mainly wheat) and by exchanging corn (slowly degradable starch) with wheat (rapidly degradable starch) in the concentrate, resulting in 4 treatments that varied in dietary mRDC level of $167,181,194$, or $208 \mathrm{~g} / \mathrm{kg}$ of dry matter. Level of mRDC did not affect dry matter intake. Fat- and protein-corrected milk production and milk fat and lactose yield were greatest at $181 \mathrm{mRDC}$ and decreased with further increases in mRDC. Milk protein yield and concentration increased with increasing mRDC level. Mean rumen $\mathrm{pH}$ and diurnal variation in ruminal $\mathrm{pH}$ did not differ between treatments. Total daily meal time and number of visits per meal were smaller at 181
\end{abstract}

Received November 8, 2016.

Accepted March 7, 2017.

${ }^{1}$ Corresponding author: Jeroen.doorenbos@trouwnutrition.com and $194 \mathrm{mRDC}$. Despite milk production responses, increasing dietary mRDC levels, while maintaining net energy and intestinal digestible protein as well as other nutrients at similar levels, did not influence rumen $\mathrm{pH}$ parameter estimates and had minor effects on feeding behavior. These results indicate that aggregating rapidly degradable carbohydrate content into one term may be a simple way to further improve predictability of production responses in practical diet formulation for lactating dairy cows.

Key words: rapidly degradable carbohydrate, rumen model, milk production, dairy cow

\section{INTRODUCTION}

Milk production and composition are of major importance to the economics of a dairy farm and to a large extent depend on energy and protein intake of the cow (Huhtanen and Nousiainen, 2012; Daniel et al., 2016). Several systems calculate $\mathrm{ME}$ or $\mathrm{NE}_{\mathrm{L}}$ and $\mathrm{MP}$ values for individual feedstuffs based on estimates of rumen fermentation and intestinal or total-tract digestibility of nutrients (Tylutki et al., 2008; Volden, 2011; CVB, 2012). Besides energy and MP supply, dairy cow performance is influenced by rumen function, the supply of rumen degradable substrates, and the profile of nutrients available in the postabsorptive metabolism (Dijkstra et al., 2012; Huhtanen and Nousiainen, 2012).

Rumen degradable substrates can be subdivided into carbohydrates and protein. Rumen degradable carbohydrates consist of different chemical components, the primary constituents being starch, NDF, sugar, and pectin. Each component has distinct ruminal degradation and fermentation characteristics. Although total VFA production is related to the intake of rumen fermentable OM, components like NDF or starch result in different proportions of individual VFA produced in the rumen (Nozière et al., 2011). Diet composition can also affect VFA proportions through interconversions between the major VFA (acetate, propionate, and butyrate; Sutton et al., 2003). These VFA have different effects on milk production and composition (Thomas and Martin, 1988). Therefore, each fraction of rumen 
degradable carbohydrates can have different effects on milk production and composition, even when energy or MP supply does not differ. Replacing starch for NDF or changing the starch source (i.e., corn vs. barley or wheat) will affect VFA molar proportions, intestinal digestibility, and metabolic responses, although not always resulting in a response in production performance (Lechartier and Peyraud, 2011; Ferraretto et al., 2013; Piccioli-Cappelli et al., 2014).

The major mechanisms to control ruminal $\mathrm{pH}$ are buffering by saliva, removal of VFA by ruminal absorption, or passage to the small intestine (Dijkstra et al., 2012). Higher ruminal VFA production through increased carbohydrate supply and fermentation rate not compensated by increased ruminal VFA absorption or buffering will lower average ruminal $\mathrm{pH}$ or increase diurnal variation in ruminal $\mathrm{pH}$. This change in $\mathrm{pH}$ dynamics can affect nutrient availability and thus affect production performance (Dijkstra et al., 2012).

Meeting the animal and microbial nutrient requirements in diet formulation will optimize cost-effective animal performance while minimizing nutrient excretion into the environment. Inclusion of several formulation bounds, required to account for dietary carbohydrate characteristics, including levels of various sources and differences in rate of degradation between and within feedstuffs, increases the complexity of diet formulation. The amount of rumen degradable carbohydrates depends on the rumen soluble, washable, and nonwashable but potentially degradable fractions, as well as the fractional degradation rate $\left(\mathrm{k}_{\mathrm{d}}\right)$ and fractional passage rate (Van Duinkerken et al., 2011). As $\mathrm{k}_{\mathrm{d}}$ is a nonlinear characteristic representing the fraction of substrate being degraded per unit of time, this value cannot be used directly in linear programming for diet formulation (Volden, 2011). Aggregating rumen degradation characteristics of the different carbohydrate components per feedstuff into terms such as modeled rapidly degradable carbohydrates (mRDC) and modeled total degradable carbohydrates (mTDC) can simplify diet formulation and still capture the effect of total carbohydrate supply as well as rate of degradation. In the present study, mRDC and mTDC are calculated for individual feedstuffs based on a simple rumen model.

The objective of our study was to evaluate production responses of lactating dairy cows to diets that were formulated to increasing $\mathrm{mRDC}$ levels, keeping the supply of other nutrients as constant as possible.

\section{MATERIALS AND METHODS}

The experiment was conducted at the Trouw Nutrition Dairy Research Facility (Kempenshof) in Boxmeer, the Netherlands. The experiment was conducted under approval of the Dutch Animal Ethics Committee according to the Experiments on Animals Act, 1977.

\section{Animals and Experimental Design}

Fifty-two lactating Holstein dairy cows (8 primiparous and 44 multiparous) averaging $144 \pm 62.7 \mathrm{DIM}$, $22.0 \pm 3.15 \mathrm{~kg}$ of $\mathrm{DM} / \mathrm{d}$ and $31.3 \pm 6.13 \mathrm{~kg}$ of milk/d at the start of the experiment were used. Four of the multiparous cows had a rumen fistula $(10 \mathrm{~cm}$ i.d., Bar-Diamond, Parma, ID). Animals were housed in a slatted-floor freestall barn and had free access to water at all times.

The experiment was set up as a $4 \times 4$ Latin square design with 4 treatments and 4 periods. Each period consisted of 2 wk of adaptation and 1 wk of measurements. Cows were assigned to a block consisting of 4 animals, according to milk yield, DMI, and DIM, based on the average value of these parameters obtained in the last $4 \mathrm{wk}$ before start of the experiment. The rumen-fistulated animals formed one block. Within each block, cows were randomly assigned to 1 of 4 different treatment sequences.

Body weights were recorded automatically 4 times per week (twice after the morning milking and twice after the evening milking).

\section{Dietary Treatments and Feeding}

The 4 treatments consisted of increasing levels of $\mathrm{mRDC}$ at $167,181,194$, and $208 \mathrm{~g}$ of $\mathrm{mRDC} / \mathrm{kg}$ of DM. Concentrate ingredient composition was used to create the differences in mRDC level for the lowest and highest mRDC diets (Table 1; low mRDC and high mRDC concentrate, respectively). The basal forage mixture consisted of grass silage, corn silage, and grass hay and was identical for all treatments (Table 2). Animals were fed ad libitum TMR, which consisted of the forage mixture supplemented with different amounts of the low $\mathrm{mRDC}$ concentrate or the high $\mathrm{mRDC}$ concentrate to create the differences between treatments (Table 3 ). The TMR were formulated to be iso-energetic based on $\mathrm{NE}_{\mathrm{L}}$ (Van Es, 1978), and iso-nitrogenous based on intestinal digestible protein (DVE) and degraded protein balance in the rumen (Tamminga et al., 1994). The TMR provided adequate net energy and intestinal digestible protein for a cow consuming $22 \mathrm{~kg}$ of DM/d and producing $32 \mathrm{~kg}$ of milk/d.

The DM content of grass silage and corn silage was analyzed weekly in a forced-air oven at $60^{\circ} \mathrm{C}$ for $48 \mathrm{~h}$ to ensure a constant composition of the TMR and DM supply to the animals. The TMR were produced daily and administered once per day in electronic forage feeders (Insentec, Marknesse, the Netherlands) after removal of 
refusals. The 13 cows per treatment were given access to 7 feeders via electronic ear transponders, allowing for individual feed intake registration per cow.

\section{Simple Rumen Carbohydrate Model for $m R D C$ Calculation}

Rumen degradable carbohydrates are defined as carbohydrates degraded in the rumen within $2 \mathrm{~h}$ after ingestion. The dietary mRDC content was calculated for individual feedstuffs using the simple model defined below. The nutrients comprising the carbohydrate fraction are NDF, starch, sugar, and residual OM [calculated as DM minus ash, CP, NDF, starch, sugar, crude fat, and fermentation acids (the latter in silages only)]. For each feedstuff and nutrient, the amount of mRDC (g/ $\mathrm{kg}$ of DM) was calculated using feedstuff-specific in situ degradation parameters, namely, washable $(\mathrm{W})$, soluble

Table 1. Ingredient composition, analyzed chemical composition, and calculated nutrient value of low and high modeled rapidly degradable carbohydrate $(\mathrm{mRDC})$ concentrates

\begin{tabular}{|c|c|c|}
\hline \multirow[b]{2}{*}{ Item } & \multicolumn{2}{|c|}{ Concentrate } \\
\hline & Low mRDC & High mRDC \\
\hline \multicolumn{3}{|c|}{ Ingredient composition ( $\mathrm{g} / \mathrm{kg}$ of $\mathrm{DM})$} \\
\hline Corn & 157 & 38 \\
\hline Wheat & - & 387 \\
\hline Bypass soybean meal & 102 & - \\
\hline Palm kernel expeller & 154 & - \\
\hline Rapeseed meal & 167 & 155 \\
\hline Bypass rapeseed meal & - & 144 \\
\hline Sunflower seed meal & - & 103 \\
\hline Sugar beet pulp & 301 & - \\
\hline Citrus pulp & 34 & - \\
\hline Soybean hulls & - & 78 \\
\hline Cane molasses & 12 & - \\
\hline Beet molasses & - & 9 \\
\hline Dextrose & - & 21 \\
\hline Urea & 20 & 8 \\
\hline Palm oil fatty acids & 17 & 7 \\
\hline Hydrogenated palm oil & - & 16 \\
\hline Limestone & - & 10 \\
\hline Salt & - & 7 \\
\hline Magnesium oxide & 4 & 3 \\
\hline Monocalcium phosphate & 17 & 8 \\
\hline Sodium bicarbonate & 10 & - \\
\hline Vitamin and mineral premix ${ }^{1}$ & 7 & 7 \\
\hline \multicolumn{3}{|c|}{ Analyzed chemical composition ( $\mathrm{g} / \mathrm{kg}$ of DM unless stated otherwise $)^{2}$} \\
\hline $\mathrm{DM}(\mathrm{g} / \mathrm{kg})$ & $898(0.4)$ & $884(0.8)$ \\
\hline $\mathrm{OM}$ & $916(0.6)$ & $931(0.4)$ \\
\hline $\mathrm{CP}$ & $243(1.2)$ & $244(1.3)$ \\
\hline NDF & $325(2.9)$ & $234(3.3)$ \\
\hline Starch & $119(6.8)$ & $305(2.3)$ \\
\hline Sugar & $76(0.5)$ & $76(1.4)$ \\
\hline Crude fat & $49(3.1)$ & $49(3.6)$ \\
\hline \multicolumn{3}{|c|}{$\begin{array}{l}\text { Calculated nutrient value (based on ingredient composition; } \mathrm{g} / \mathrm{kg} \text { of DM } \\
\text { unless stated otherwise) }\end{array}$} \\
\hline $\mathrm{NE}_{\mathrm{L}}^{3}(\mathrm{MJ} / \mathrm{kg}$ of DM) & 7.50 & 7.49 \\
\hline $\mathrm{DVE}^{4}$ & 141 & 137 \\
\hline $\mathrm{OEB}^{5}$ & 45 & 47 \\
\hline $\mathrm{mRDC}^{6}$ & 167 & 271 \\
\hline $\mathrm{mTDC}^{6}$ & 411 & 448 \\
\hline Bypass starch $^{6}$ & 50 & 43 \\
\hline \multicolumn{3}{|c|}{$\begin{array}{l}{ }^{1} \text { Contained per kilogram of premix: } 84 \mathrm{~g} \text { of } \mathrm{Ca}, 125 \mathrm{mg} \text { of } \mathrm{Co}, 250 \mathrm{mg} \text { of } \mathrm{I}, 2,500 \mathrm{mg} \text { of } \mathrm{Cu}, 3,333 \mathrm{mg} \text { of } \mathrm{Mn}, 110 \\
\mathrm{mg} \text { of Se, 8,333 mg of } \mathrm{Zn}, 1,333,300 \mathrm{IU} \text { of vitamin } \mathrm{A}, 333,300 \mathrm{IU} \text { of vitamin } \mathrm{D}_{3} \text {, and } 25,906 \mathrm{IU} \text { of vitamin E. } \\
{ }^{2} \mathrm{Mean} \pm \mathrm{SE} \text {; SE based on composited sample per period }(\mathrm{n}=4) \text {. } \\
{ }^{3} \mathrm{Calculated} \mathrm{NE}_{\mathrm{L}} \text { (Van Es, 1978). } \\
{ }^{4} \text { Calculated intestinal digestible protein (Tamminga et al., 1994). } \\
{ }^{5} \text { Calculated degraded protein balance in the rumen (Tamminga et al., 1994). } \\
{ }^{6} \mathrm{mRDC}=\text { modeled rapidly degradable carbohydrates; mTDC = modeled total degradable carbohydrates. } \\
\text { For calculation of mRDC, mTDC, and bypass starch, see Materials and Methods, simple rumen carbohydrate } \\
\text { model for mRDC calculation. }\end{array}$} \\
\hline
\end{tabular}


Table 2. Analyzed chemical composition ( $\mathrm{g} / \mathrm{kg}$ of DM unless stated otherwise) and calculated nutrient value $(\mathrm{g} / \mathrm{kg}$ of DM unless stated otherwise) of forages [mean $\pm \mathrm{SE}$; SE based on composited sample per period $(\mathrm{n}=4)]$

\begin{tabular}{|c|c|c|c|}
\hline Item & Corn silage & Grass silage & Grass hay \\
\hline \multicolumn{4}{|c|}{ Analyzed chemical composition } \\
\hline $\mathrm{DM}(\mathrm{g} / \mathrm{kg}$ as fed) & $330(6.6)$ & $446(8.9)$ & $852(5.3)$ \\
\hline $\mathrm{OM}$ & $962(0.2)$ & $867(4.7)$ & $942(4.9)$ \\
\hline $\mathrm{CP}$ & $77(1.5)$ & $170(4.1)$ & $74(6.5)$ \\
\hline NDF & $375(2.9)$ & $490(10.3)$ & $688(7.9)$ \\
\hline Starch & $344(4.4)$ & $\mathrm{NA}^{1}$ & NA \\
\hline Sugar & $10(0.4)$ & $26(2.2)$ & $84(7.8)$ \\
\hline Crude fat & $34(0.8)$ & $38(0.8)$ & $16(1.1)$ \\
\hline OM digestibility (\%) & $77.1(0.54)$ & $74.7(0.47)$ & $55.8(0.61)$ \\
\hline \multicolumn{4}{|l|}{ Calculated nutrient value } \\
\hline $\mathrm{NE}_{\mathrm{L}}^{2}(\mathrm{MJ} / \mathrm{kg}$ of DM) & 6.89 & 5.83 & 4.16 \\
\hline $\mathrm{DVE}^{3}$ & 53 & 68 & 38 \\
\hline $\mathrm{OEB}^{4}$ & -29 & 54 & -39 \\
\hline $\mathrm{mRDC}^{5}$ & 219 & 137 & 110 \\
\hline $\mathrm{mTDC}^{5}$ & 495 & 391 & 343 \\
\hline Bypass starch ${ }^{5}$ & 68 & 0 & 0 \\
\hline \multicolumn{4}{|c|}{${ }^{1} \mathrm{NA}=$ not analyzed. } \\
\hline \multicolumn{4}{|c|}{${ }^{2}$ Calculated $\mathrm{NE}_{\mathrm{L}}($ Van Es, 1978). } \\
\hline \multicolumn{4}{|c|}{${ }^{3}$ Calculated intestinal digestible protein (Tamminga et al., 1994). } \\
\hline \multicolumn{4}{|c|}{${ }^{4}$ Calculated degraded protein balance in the rumen (Tamminga et al., 1994). } \\
\hline \multicolumn{4}{|c|}{$\begin{array}{l}{ }^{5} \mathrm{mRDC}=\text { modeled rapidly degradable carbohydrates; mTDC }=\text { modeled total degradable carbohydrates } \\
\text { For calculation of mRDC, mTDC, and bypass starch, see Materials and Methods, simple rumen carbohydrate } \\
\text { model for mRDC calculation. }\end{array}$} \\
\hline
\end{tabular}

(S), and nonwashable but potentially degradable (D) fraction (all fractions in $\mathrm{g} / \mathrm{kg}$ per nutrient), with WS (washable but insoluble fraction; $\mathrm{g} / \mathrm{kg}$ of nutrient) calculated as $\mathrm{W}-\mathrm{S}$, together with the fractional rate of degradation $\left(\mathrm{k}_{\mathrm{d}} ; / \mathrm{h}\right)$ and fractional rate of passage $\left(\mathrm{k}_{\mathrm{p}}\right.$; $/ \mathrm{h}$ ) of each fraction according to the formula of Ørskov and McDonald (1979) using a time after ingestion of 2 h:

$$
\begin{gathered}
\text { Rapidly degradable nutrient }=\text { Nutrient } \\
\times\left(\mathrm{S} \times \mathrm{k}_{\mathrm{d}} \mathrm{S} /\left(\mathrm{k}_{\mathrm{d}} \mathrm{S}+\mathrm{k}_{\mathrm{p}} \mathrm{S}\right) \times\left\{1-\exp \left[-\left(\mathrm{k}_{\mathrm{p}} \mathrm{S}+\mathrm{k}_{\mathrm{d}} \mathrm{S}\right)\right.\right.\right. \\
\times \text { time }]\}+\mathrm{WS} \times \mathrm{k}_{\mathrm{d}} \mathrm{WS} /\left(\mathrm{k}_{\mathrm{d}} \mathrm{WS}+\mathrm{k}_{\mathrm{p}} \mathrm{WS}\right) \\
\times\left\{1-\exp \left[-\left(\mathrm{k}_{\mathrm{p}} \mathrm{WS}+\mathrm{k}_{\mathrm{d}} \mathrm{WS}\right) \times \text { time }\right]\right\}+\mathrm{D} \times \mathrm{k}_{\mathrm{d}} \mathrm{D} / \\
\left.\left(\mathrm{k}_{\mathrm{d}} \mathrm{D}+\mathrm{k}_{\mathrm{p}} \mathrm{D}\right) \times\left\{1-\exp \left[-\left(\mathrm{k}_{\mathrm{p}} \mathrm{D}+\mathrm{k}_{\mathrm{d}} \mathrm{D}\right) \times \text { time }\right]\right\}\right) .
\end{gathered}
$$

The degradation parameter values and fractional degradation and passage rates for concentrate ingredients and grass hay used in these calculations were according to Van Duinkerken et al. (2011) with minor modifications (Appendix Table A1). Degradation parameters and fractional degradation rates of grass silage and corn silage were calculated using regression equations that were derived from a data set of in situ incubations according to the methodology described by Van Laar and Doorenbos (2014). Fractional passage rates of grass and corn silage are presented in Appendix Table A1.

Modeled total degradable carbohydrate content was calculated similar to mRDC, in this case with time after ingestion to be infinite. Bypass starch was calculated as dietary starch minus rumen degraded starch, also as estimated by in situ degradability and passage rates.

\section{Milk Yield and Composition}

Cows were milked twice daily at 0500 and $1700 \mathrm{~h}$. Milk yield was recorded automatically at each milking. Milk was sampled every week at Tuesday and Thursday morning and Monday and Wednesday evening milking events to represent the full week. Samples were collected in tubes containing sodium azide and bronopol as preservatives and stored at $4^{\circ} \mathrm{C}$. Morning samples as well as evening samples were pooled and analyzed for fat, CP, lactose, and urea (Qlip, Deventer, the Netherlands) using a Foss Milkoscan FT6000 (ISO, 2013). Somatic cell count was analyzed in the same sample using a Fossomatic FC/5000 (ISO, 2006a). Fat- and protein-corrected milk yield (FPCM, corrected to $4.0 \%$ fat and $3.3 \%$ protein; $\mathrm{kg} / \mathrm{d}$ ) was calculated as milk yield $(\mathrm{kg} / \mathrm{d}) \times[0.377+0.116 \times$ fat $(\%)+0.06 \times$ protein (\%)]. Feed efficiency was expressed as kilogram of milk or FPCM produced per kilogram of DMI. 
Table 3. Ingredient composition, calculated chemical composition, and calculated nutrient value, for the 4 dietary treatments differing in modeled rapidly degradable carbohydrate (mRDC) level

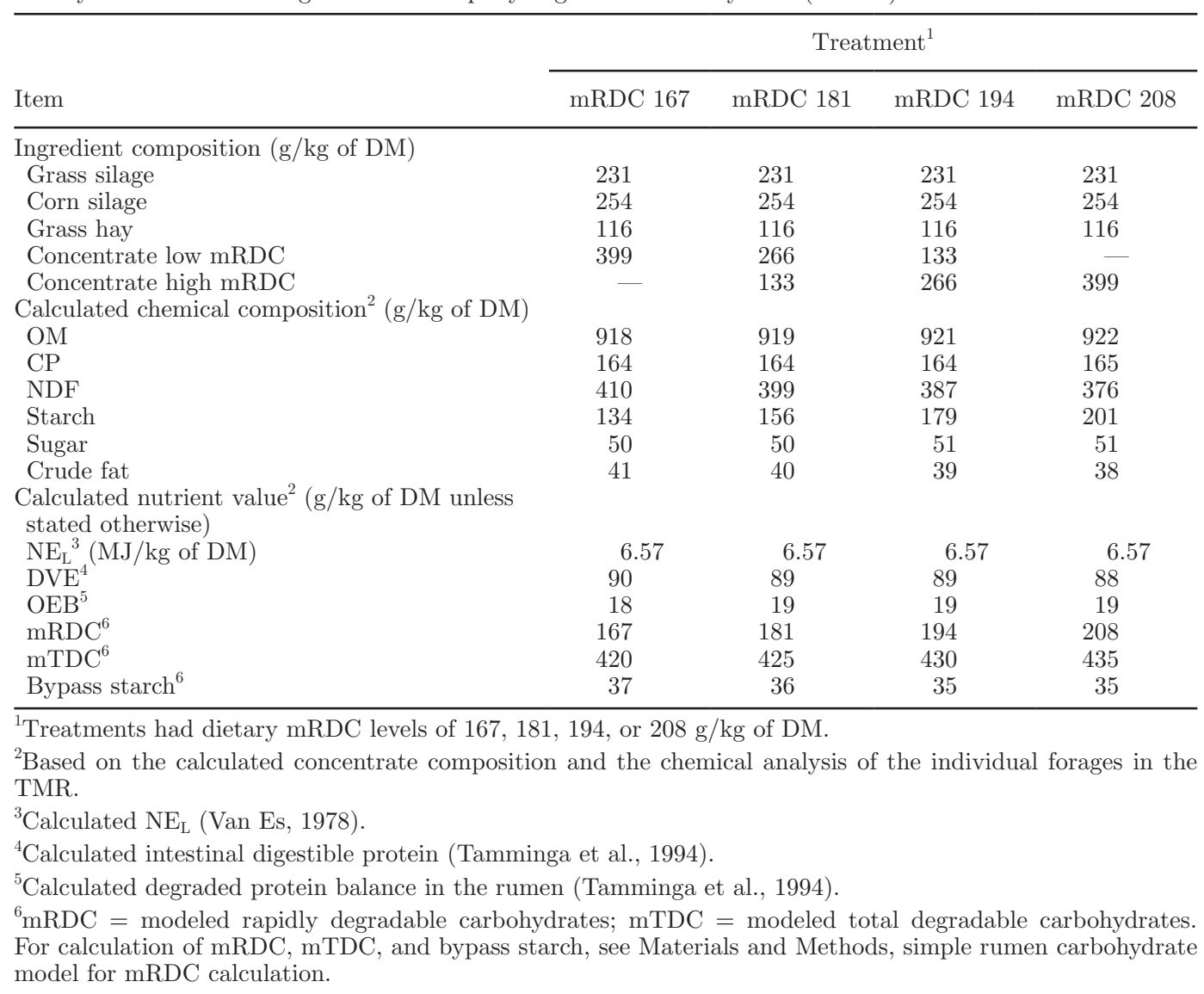

\section{Rumen $\mathrm{pH}$}

Rumen $\mathrm{pH}$ was recorded every 2 min with a $\mathrm{pH} \log$ ger (LRCpH T7 logger, Dascor, Escondido, CA). Loggers were inserted in the rumen of 4 fistulated animals the day before the start of the last week of each period and removed on the last day of that same week. At the beginning and end of the measuring period, loggers were calibrated in $\mathrm{pH} 4$ and $\mathrm{pH} 7$ buffers and recordings were corrected for drift in $\mathrm{pH}$ over time. The $\mathrm{pH}$ data were analyzed according to the method described by Colman et al. (2012). In brief, pH data were recalculated to the minutes per day that $\mathrm{pH}$ was below a certain value, ranging from $\mathrm{pH} 5.0$ to 7.4, with steps of 0.1 . This results in a cumulative time below $\mathrm{pH}$ graph, with $\mathrm{pH}$ on the $\mathrm{x}$-axis and minutes per day below a certain $\mathrm{pH}$ on the y-axis. For each cow and week, a logistic curve was fitted through the data points with PROC NLIN of SAS version 9.4 (SAS Institute Inc., Cary, NC) according to the model: $\mathrm{T}=1,440 /\left\{1+\exp \left[-\mathrm{B}_{0} \times\right.\right.$ $\left.\left.\left(\mathrm{pH}-\mathrm{B}_{1}\right)\right]\right\}$, where $\mathrm{T}$ is the cumulative time below $\mathrm{pH}$ $(\mathrm{min} / \mathrm{d})$. The parameters describing the curve are $\mathrm{B}_{0}$ (slope at the inflection point) and $\mathrm{B}_{1}$ (inflection point).
$\mathrm{B}_{0}$ reflects the diurnal variation in ruminal $\mathrm{pH}$ and $\mathrm{B}_{1}$ is the median rumen $\mathrm{pH}$.

\section{Feeding Behavior Data Collection and Analysis}

For every visit of a cow to a feeder, the start and end time of the visit as well as the start and end weight of the feeder were recorded. Visits without intake $(12 \%$ of total visits), with a rate of intake less than $0.005 \mathrm{~kg}$ of $\mathrm{DM} / \mathrm{min}(0.1 \%$; animals spending much time at the feeder without actual intake) or with a rate of intake larger than $1.5 \mathrm{~kg}$ of $\mathrm{DM} / \mathrm{min}(0.2 \%$; expected to be caused by feed wastage) were removed from the data set.

Feeding behavior was analyzed according to Yeates et al. (2001). Time interval (in seconds) between 2 consecutive visits was transformed with a natural logarithm. For every cow a 2-population model (Gaussian-Weibull; GW) and a 3-population model (Gaussian-GaussianWeibull; GGW) was fitted through the individual transformed time intervals using the finite mixture models (FMM) procedure of SAS 9.4 (SAS Institute Inc.). In the GW model, the 2 populations describe 
the time intervals within meals and the time intervals between meals, respectively. In the GGW model, the 2 Gaussian distributions describe within-meal intervals and the Weibull distribution describes the betweenmeal interval. Per cow and treatment, the relevance of adding a second $\mathrm{G}$ distribution was determined based on the likelihood ratio test (Yeates et al., 2001). A significant lower $-2 \log$-likelihood value indicates that the GGW model improved the goodness of fit of the data as compared with the GW model, and the GGW model was selected. Otherwise the GW model was selected. For each selected model, a meal criterion was determined as the intersection between the Gaussian and the Weibull curve (GW model) or the intersection between the second Gaussian and the Weibull curve (GGW model). This meal criterion is used to describe the longest interval between 2 consecutive visits that are still part of the same meal. Visits were clustered into meals per day by using the meal criterion and total daily meal time was calculated. Total daily eating time was calculated as total daily meal time minus intervals within meals. Per meal, the number of visits, mean meal duration, eating time, DMI, and rate of DMI [DMI $(\mathrm{kg})$ per meal, divided by eating time (min) per meal] were calculated (Abrahamse et al., 2008).

\section{Sampling and Chemical Analyses}

During every third week of each period, concentrates and forages were sampled and stored at $-18^{\circ} \mathrm{C}$ until further analysis. Concentrates were sent to Masterlab (Boxmeer, the Netherlands) and forages to AgroXpertus (Wageningen, the Netherlands). Concentrates were analyzed for DM, ash, CP, crude fat, NDF, starch, and sugar after grinding to $0.75 \mathrm{~mm}$ using a Retsch ZM200 mill (Retsch, Haan, Germany). Dry matter was determined after drying for $4 \mathrm{~h}$ at $103^{\circ} \mathrm{C}$ (EC 152/2009; EC, 2009). Ash was determined after incineration at $550^{\circ} \mathrm{C}$ (EC 152/2009; EC, 2009). Crude protein was determined according to the Dumas principle (ISO 16634-1; ISO, 2008). Crude fat was determined by treating the sample with hydrochloric acid and subsequent extracting with petroleum (EC 152/2009; EC, 2009). Amylase-treated NDF was determined using heat stable $\alpha$-amylase and expressed without residual ash (ISO 16472; ISO, 2006b). Starch was determined enzymatically using amyloglucosidase (ISO 15914; ISO, 2004). Sugar was determined according to the Luff-Schoorl method and expressed as glucose (71/250/ EEC; EC, 1971).

Forages were analyzed for DM, ash, CP, crude fat, NDF, starch, sugar, and OM digestibility. Samples were dried for $16 \mathrm{~h}$ at $70^{\circ} \mathrm{C}$ and ground at $1 \mathrm{~mm}$ (ISO 16498;
ISO, 2012). Dry matter, ash, crude fat, and starch were analyzed using the same methods as for concentrates. Crude protein was analyzed according to the Kjeldahl principle (EC 152/2009; EC, 2009). Amylase-treated NDF was determined using heat-stable $\alpha$-amylase and expressed without residual ash (AOAC International, 2002). Sugar was determined according to the LuffSchoorl method and expressed as glucose (EC 152/2009; EC, 2009). Organic matter digestibility was determined after $48 \mathrm{~h}$ incubation in rumen fluid and subsequently $48 \mathrm{~h}$ incubation in a pepsin- $\mathrm{HCl}$ solution according to Tilley and Terry (1963).

\section{Statistical Analyses}

The results of the third experimental period had to be removed from the data set due to problems with feed preparation. Data of 5 cows were excluded because occurrence of mastitis (2 cows), leg problems (2 cows), and general health problems (1 cow) that led to nonrepresentative data. As a result, the number of replicates used in the statistical analysis was 36 for treatment 1 , 2 , and 3 , and 34 for treatment 4 . For the analysis of the $\mathrm{pH}$ variables, 3 replicates per treatment were used. For individual cows, all data were averaged into weekly results per period. Feed intake, milk and component yield, milk composition, feed efficiency, BW change, $\mathrm{pH}$ variables, and feeding behavior characteristics were analyzed as repeated measurements with PROC MIXED of SAS 9.4 (SAS Institute Inc.) according to the following model:

$$
Y_{i j k}=\mu+\mathrm{mRDC}_{i}+\text { Square }_{j}+\operatorname{Period}_{k}+\varepsilon_{i j k},
$$

where $Y$ is the dependent variable, $\mu$ is the overall mean, and $\varepsilon_{i j k}$ is the residual error. The model included the fixed effects of level of $\mathrm{mRDC}\left(\mathrm{mRDC}_{i} ; i=1\right.$ to 4), square ( Square $_{j} ; j=1$ to 4 ; not for $\mathrm{pH}$ variables), and period ( Period $_{k} ; k=1$ to 3 ). Block was used as a random effect. Period was the repeated effect, with cow being the random subject. The covariance structure chosen was based on Akaike information criterion and Bayesian information criterion best fit. Covariance structure was autoregressive (1) for milk fat concentration, milk protein concentration, milk urea, diet and FPCM efficiency, BW change, all $\mathrm{pH}$ parameters, meals per day, visits per meal, eating time per meal, DMI per meal, and rate of DMI per meal. Toeplitz covariance structure was used for total daily meal time and total daily eating time, and ante (1) covariance structure was used for all other parameters. Orthogonal contrasts were used to test for linear, quadratic, or cubic effects of mRDC level. Linear, quadratic, or cubic effects of 
Table 4. Dry matter intake and production performance of lactating dairy cows offered diets with different levels of modeled rapidly degradable carbohydrates (mRDC)

\begin{tabular}{|c|c|c|c|c|c|c|c|c|}
\hline \multirow[b]{2}{*}{ Item } & \multicolumn{4}{|c|}{ Treatment $^{1}$} & \multirow[b]{2}{*}{ SEM } & \multicolumn{3}{|c|}{$P$-value ${ }^{2}$} \\
\hline & mRDC 167 & mRDC 181 & mRDC 194 & mRDC 208 & & $\mathrm{~L}$ & $\mathrm{Q}$ & $\mathrm{C}$ \\
\hline Milk & 27.8 & 28.6 & 28.0 & 27.7 & 1.4 & 0.42 & Yield (kg/d) & 0.06 \\
\hline $\mathrm{FPCM}^{3}$ & $\begin{array}{l}21.0 \\
29.2\end{array}$ & $\begin{array}{l}20.0 \\
30.4\end{array}$ & $\begin{array}{l}20.0 \\
29.6\end{array}$ & 29.4 & $\begin{array}{l}1.4 \\
1.4\end{array}$ & $\begin{array}{l}0.42 \\
0.79\end{array}$ & 0.03 & 0.02 \\
\hline Milk fat & 1.22 & 1.27 & 1.23 & 1.21 & 0.06 & 0.32 & 0.06 & 0.03 \\
\hline \multicolumn{9}{|l|}{ Milk composition (\%) } \\
\hline Milk fat & 4.40 & 4.46 & 4.43 & 4.34 & 0.07 & 0.22 & 0.07 & 0.69 \\
\hline Milk protein & 3.47 & 3.55 & 3.55 & 3.59 & 0.04 & $<0.01$ & 0.28 & 0.07 \\
\hline Milk lactose & 4.47 & 4.48 & 4.50 & 4.48 & 0.04 & 0.30 & 0.20 & 0.48 \\
\hline Milk urea $(\mathrm{mg} / \mathrm{dL})$ & 27.0 & 28.1 & 26.4 & 27.2 & 0.6 & 0.51 & 0.68 & $<0.01$ \\
\hline $\operatorname{SCC}\left(10^{3} / \mathrm{mL}\right)$ & 228 & 176 & 148 & 163 & 40 & 0.09 & 0.73 & 0.86 \\
\hline \multicolumn{9}{|l|}{ Efficiency $(\mathrm{kg} / \mathrm{kg})$} \\
\hline
\end{tabular}

${ }^{1}$ Treatments had dietary mRDC levels of $167,181,194$, or $208 \mathrm{~g} / \mathrm{kg}$ of DM.

${ }^{2} \mathrm{~L}=$ linear; $\mathrm{Q}=$ quadratic; $\mathrm{C}=$ cubic.

${ }^{3} \mathrm{FPCM}=$ fat- and protein-corrected milk yield.

treatments were declared significant at $P<0.05$ and as trends at $0.05 \leq P<0.10$. Results are presented as least squares means.

\section{RESULTS}

Forage supply was identical across treatments, and therefore dietary mRDC contrasts between the treatments originated exclusively from concentrate composition. Dietary mRDC level tended to have a linear $(P=$ $0.06)$ and cubic effect on DMI $(P=0.05$; Table 4$)$. Milk production tended to respond quadratically $(P=0.07)$ and cubically $(P=0.06)$ to $\mathrm{mRDC}$, whereas FPCM showed quadratic $(P=0.03)$ and cubic $(P=0.02)$ responses to mRDC level. Milk fat yield responded cubically to mRDC level $(P=0.03)$ and tended to respond quadratically $(P=0.06)$. Milk protein yield increased linearly with increasing mRDC level $(P=0.04)$ and tended to respond in a quadratic $(P=0.09)$ and cubic manner $(P=0.08)$ to $\mathrm{mRDC}$ level. Milk lactose yield showed a quadratic response to $\mathrm{mRDC}$ level $(P$ $=0.02)$. Milk fat concentration tended $(P=0.07)$ to respond quadratically. Increasing $\mathrm{mRDC}$ level linearly increased milk protein concentration $(P<0.01)$ and tended to affect milk protein concentration cubically $(P$ $=0.07)$. Milk urea showed a cubic response $(P<0.01)$ to mRDC level. The SCC tended to decrease linearly with increasing mRDC $(P=0.09)$. Dietary mRDC level did not affect milk lactose concentration, efficiency $(\mathrm{kg}$ of milk/ $\mathrm{kg}$ of DMI and $\mathrm{kg}$ of FPCM $/ \mathrm{kg}$ of DMI), or BW change.

Rumen $\mathrm{pH}$, described by the parameters $\mathrm{B}_{0}$ (slope) and $\mathrm{B}_{1}$ (inflection point) of the logistic curve of time spent below a certain $\mathrm{pH}$, was not affected by $\mathrm{mRDC}$ level (Table 5, Figure 1). In agreement with this observation, measured mean $\mathrm{pH}$ and cumulative time

Table 5. Rumen $\mathrm{pH}$ data of lactating dairy cows offered diets with different levels of modeled rapidly degradable carbohydrates (mRDC) ${ }^{1}$

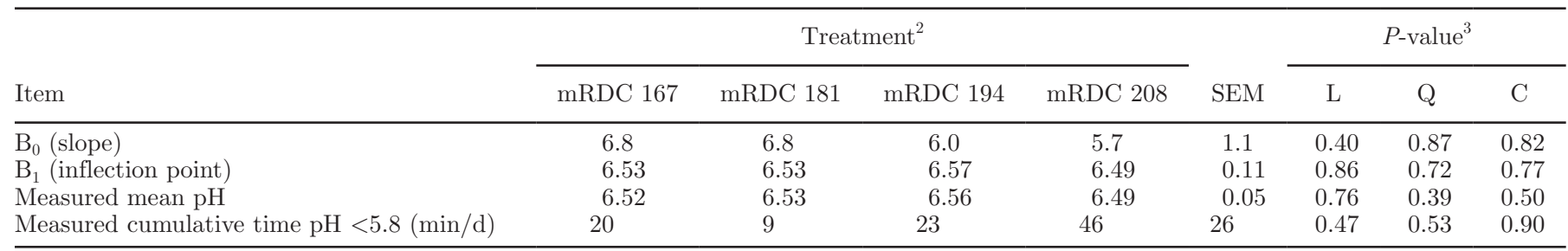

${ }^{1}$ Based on data of 4 rumen-fistulated animals per period.

${ }^{2}$ Treatments had dietary mRDC levels of $167,181,194$, or $208 \mathrm{~g} / \mathrm{kg}$ of DM.

${ }^{3} \mathrm{~L}=$ linear; $\mathrm{Q}=$ quadratic; $\mathrm{C}=$ cubic. 
Table 6. Feeding behavior of lactating dairy cows offered diets with different levels of modeled rapidly degradable carbohydrates (mRDC)

\begin{tabular}{|c|c|c|c|c|c|c|c|c|}
\hline Item & \multicolumn{4}{|c|}{ Treatment $^{1}$} & SEM & \multicolumn{3}{|c|}{$P$-value ${ }^{2}$} \\
\hline Meal criterion (min) & 32.5 & 31.8 & 24.4 & 35.3 & 3.4 & 0.94 & 0.07 & 0.07 \\
\hline Meals (no.) & 5.5 & 5.6 & 5.8 & 5.7 & 0.2 & 0.31 & 0.43 & 0.79 \\
\hline Total daily meal time (min) & 266 & 252 & 251 & 269 & 9 & 0.83 & 0.02 & 0.82 \\
\hline Total daily eating time (min) & 220 & 214 & 223 & 220 & 9 & 0.57 & 0.53 & 0.10 \\
\hline Meal duration (min) & 49.7 & 48.4 & 45.9 & 50.8 & 2.8 & 0.93 & 0.19 & 0.40 \\
\hline Eating time $(\min )$ & 42.2 & 40.1 & 39.5 & 40.4 & 1.9 & 0.34 & 0.28 & 0.99 \\
\hline DMI $(\mathrm{kg})$ & 4.1 & 4.0 & 4.1 & 4.1 & 0.2 & 0.97 & 0.73 & 0.73 \\
\hline Rate of DMI ( $\mathrm{g} / \mathrm{min}$ eating time) & 103 & 107 & 107 & 104 & 5 & 0.70 & 0.19 & 0.90 \\
\hline
\end{tabular}

${ }^{1}$ Treatments had dietary mRDC levels of $167,181,194$, or $208 \mathrm{~g} / \mathrm{kg}$ of DM.

${ }^{2} \mathrm{~L}=$ linear; $\mathrm{Q}=$ quadratic; $\mathrm{C}=$ cubic.

(min/d) of $\mathrm{pH}$ below 5.8 did not differ between treatments.

Although meal criterion tended to be affected quadratically and cubically by $\mathrm{mRDC}$ level $(P=0.07)$. the number of meals per day was not different (Table 6 ). Total daily meal time responded quadratically to mRDC level $(P=0.02)$, but total daily eating time was not affected. The number of visits per meal responded quadratically to mRDC level $(P<0.01)$. Meal duration, eating time, DMI, and rate of DMI per meal were not affected by mRDC level.

\section{DISCUSSION}

Diets formulated to be iso-energetic and isonitrogenous with increasing levels of mRDC resulted in significant production responses in this study. Milk production tended to be responsive to $\mathrm{mRDC}$, and milk fat yield and FPCM were significantly influenced by mRDC, either quadratically or cubically. Additionally, milk protein yield and milk protein concentration linearly increased with increasing level of mRDC. Because calculated bypass starch and sugar content were almost

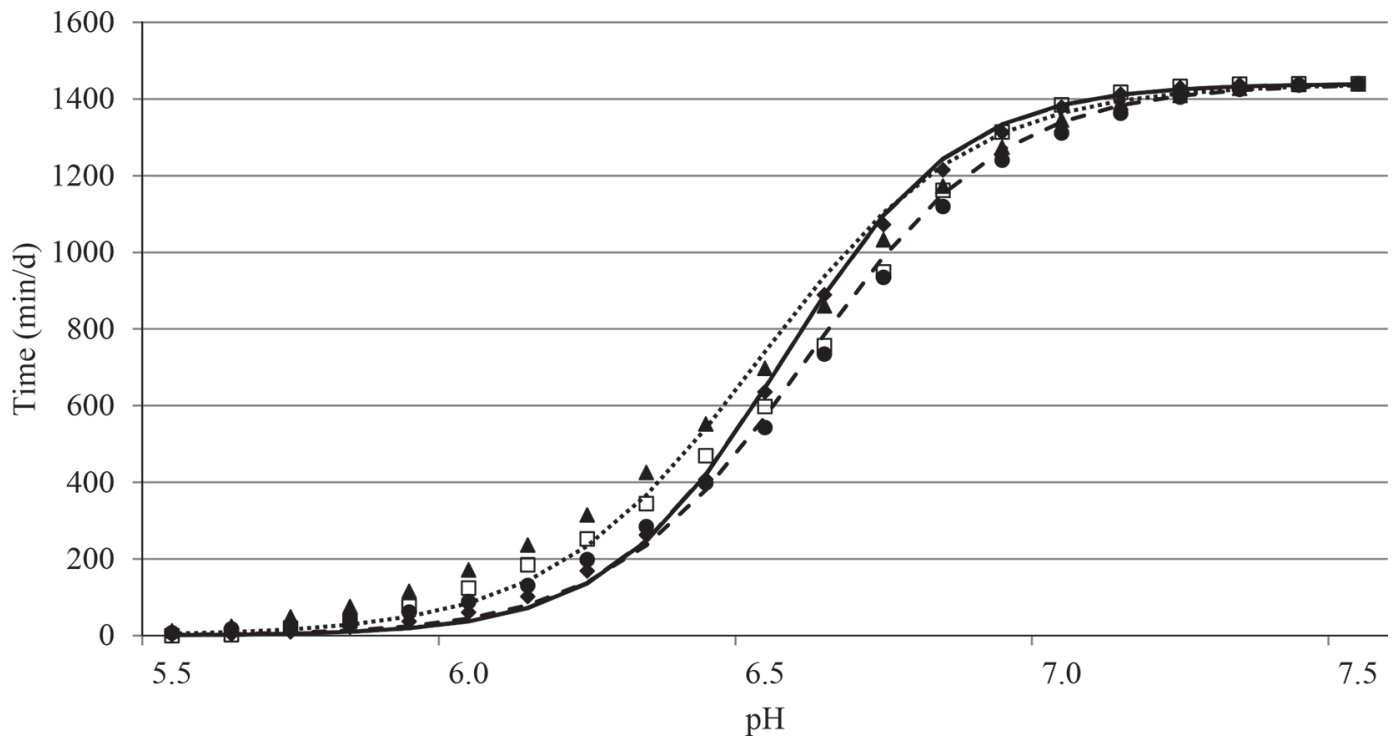

Figure 1. Effect of dietary modeled rapidly degradable carbohydrate (mRDC) level on measured time below a certain rumen pH ( $\square$ : 167 $\mathrm{g}$ of $\mathrm{mRDC} / \mathrm{kg}$ of DM; : $181 \mathrm{~g}$ of $\mathrm{mRDC} / \mathrm{kg}$ of DM; $: 194 \mathrm{~g} \mathrm{of} \mathrm{mRDC} / \mathrm{kg}$ of DM; $\mathbf{\Delta}: 208 \mathrm{~g}$ of mRDC/kg of DM) or described by a logistic curve (solid line: $167 \mathrm{~g}$ of $\mathrm{mRDC} / \mathrm{kg}$ of $\mathrm{DM}, \mathrm{B}_{0}=6.8, \mathrm{~B}_{1}=6.53$; long-dash line: $181 \mathrm{~g}$ of $\mathrm{mRDC} / \mathrm{kg}$ of $\mathrm{DM}, \mathrm{B}_{0}=6.8, \mathrm{~B}_{1}=6.53 ;$ short-dash line: $194 \mathrm{~g}$ of $\mathrm{mRDC} / \mathrm{kg}$ of $\mathrm{DM}, \mathrm{B}_{0}=6.0, \mathrm{~B}_{1}=6.57$; dotted line: $208 \mathrm{~g}$ of $\mathrm{mRDC} / \mathrm{kg}$ of $\left.\mathrm{DM}, \mathrm{B}_{0}=5.7, \mathrm{~B}_{1}=6.49\right)$. The parameters describing the logistic curve are $\mathrm{B}_{0}$ (indicating slope at the inflection point) and $\mathrm{B}_{1}$ (indicating the inflection point), respectively. $\mathrm{B}_{0}$ and $\mathrm{B}_{1}$ are unaffected by the mRDC level $(P>0.05)$. 
identical between treatments and mTDC only slightly increased with increasing $\mathrm{mRDC}$, these results can mainly be attributed to differences in mRDC. Theoretically, iso-energetic and iso-nitrogenous diets should not result in differences in milk production response. However, the observed responses in our study can potentially be explained by (1) potential inaccuracies in the calculation of $\mathrm{NE}_{\mathrm{L}}$ and MP supply, or (2) biological effects (such as effects on DMI, rumen degradation and fermentation, or metabolic effects) that are not captured by the concept of an accurately calculated $\mathrm{NE}_{\mathrm{L}}$ and $\mathrm{MP}$.

\section{Potential Inaccuracies in the Calculation of $N E_{L}$ and MP Supply}

The $\mathrm{NE}_{\mathrm{L}}$ system used for diet formulation is based on total-tract digestibility of ingested nutrients and does not take into account differences in rumen degradation and fermentation or the site of digestion between distinct carbohydrate fractions along the gastrointestinal tract. Diets in our study were formulated to have comparable bypass starch levels between treatments, and thus are not expected to result in differences in small intestinal glucose supply. Ruminal VFA concentrations were not determined in our study, but are expected to differ between treatments due to differences in ruminal carbohydrate degradation characteristics with changes in mRDC (Nozière et al., 2011). This in turn can affect milk production and composition (Thomas and Martin, 1988) even when the calculated $\mathrm{NE}_{\mathrm{L}}$ content of diets is similar. For our study, this could possibly be an explanation for the differences observed especially in milk, FPCM, and milk fat production.

Observed effects on the increase in milk protein yield and concentration with increasing $\mathrm{mRDC}$ could be related to changes in microbial protein production. The DVE system of Tamminga et al. (1994) used for diet formulation assumes a fixed efficiency of microbial protein production per gram of fermented OM. However, Van Duinkerken et al. (2011) applied varying efficiencies for microbial protein production depending on the type of substrate degraded in the rumen. Although diets were formulated to similar DVE level, increasing starch at the expense of NDF in the diets with increasing mRDC might have improved the efficiency of microbial protein synthesis (Fanchone et al., 2013), resulting in an increased flow of microbial protein and AA to the small intestine.

\section{Metabolic Effects}

It can be expected that other mechanisms in addition to total energy or MP supply play a role in lactating dairy cow performance. Rumen degradation and fermentation differ between carbohydrate fractions, resulting in changes in available energy and MP yielding nutrients, as well as influencing rumen health, metabolic pathways, and hormone levels (Nozière et al., 2011; Dijkstra et al., 2012; Arriola Apelo et al., 2014).

Arriola Apelo et al. (2014) reported that blood flow, mammary nutrient uptake, and subsequent milk protein synthesis are influenced by certain specific AA, energy substrates, and hormones. Similar to our own findings, milk protein yield and concentration increased in highstarch compared with high-NDF diets, as described by Piccioli-Cappelli et al. (2014) and Cantalapiedra-Hijar et al. (2015). These authors reported increased blood insulin concentration with high-starch feeding, which, together with branched-chain AA, may regulate mammalian target of rapamycin complex 1 (mTORC1) and milk protein synthesis (Arriola Apelo et al., 2014). Another possible explanation for the observed effects on milk protein is the observation by CantalapiedraHijar et al. (2014) that starch-rich diets can result in a lower energy requirement of the portal-drained viscera, thereby saving AA for other purposes. Data on the AA sparing effect due to glucose availability in the small intestine, which in turn could result in higher milk protein yield, are controversial (Cantalapiedra-Hijar et al., 2014; Piccioli-Cappelli et al., 2014). For our study this is less relevant as calculated bypass starch content was comparable between diets.

As discussed by Cantalapiedra-Hijar et al. (2014), carbohydrate composition can change the use of $\mathrm{N}$ for milk protein production even when energy and $\mathrm{N}$ intake do not differ. Similarly, Rigout et al. (2003) concluded that differences exist in milk fat production and possibly in milk protein production between propionate and glucose, and that the nature of energy yielding nutrients should be taken into account in diet formulation. Huhtanen and Nousiainen (2012) demonstrated a quadratic effect of increased NFC content on milk and milk protein production, although the authors mentioned that the relevance of the response, even though significant, was small. However, NFC does not take into account differences in carbohydrate components in terms of rumen degradation, fermentation, and subsequent metabolites. In the overview of Huhtanen and Nousiainen (2012), the maximum response for milk protein yield occurred at higher NFC levels than for milk yield. This indicates that milk protein concentration continues to increase with higher NFC levels where milk yield already starts to decrease, which is in line with the increase in milk protein concentration and milk protein yield with increasing $\mathrm{mRDC}$ levels in our experiment. 


\section{Rumen pH Effects}

Besides metabolic effects or potential inaccuracies in the calculation of $\mathrm{NE}_{\mathrm{L}}$ and $\mathrm{MP}$, differences in production performance can also be caused by changes in $\mathrm{pH}$ dynamics (Dijkstra et al., 2012). The level of mRDC did not affect rumen $\mathrm{pH}$ parameter estimates in our study. Average $\mathrm{pH}$ measured as mean $\mathrm{pH}$ or as the inflection point of the logistic curve was relatively high and well above the $\mathrm{pH}$ threshold of 6.0 to 6.3 given by Dijkstra et al. (2012), below which rumen fiber fermentation may be impaired. The slope of the logistic curve represents diurnal variation in $\mathrm{pH}$. A higher slope indicates a more stable rumen fermentation process with less time in which $\mathrm{pH}$ is low or high (Colman et al., 2012). In our study, forage fiber was identical across treatments and NDF levels were relatively high. Forage NDF of the diets (228 $\mathrm{g}$ of NDF from forage per total diet DM) is well above the NRC (2001) recommendation of $190 \mathrm{~g} /$ $\mathrm{kg}$ of DM to support rumen health. Feeding increasing levels of mRDC up to $208 \mathrm{~g} / \mathrm{kg}$ of DM, as in our study, should not challenge rumen stability. Based on the rumen $\mathrm{pH}$ parameter estimates, it is not expected that milk fat depression occurred due to changes in rumen fermentation. The increase in $\mathrm{mRDC}$ could have led to a lower concentration of acetate (Krause et al., 2003; Lechartier and Peyraud, 2011) or a higher formation of several trans-fatty acids in the rumen (Bauman and Griinari, 2003), which are associated with a lower milk fat production, which could potentially be an explanation for the observed decrease in milk fat yield and concentration with increasing mRDC from $181 \mathrm{mRDC}$ onward.

\section{DMI and Feeding Behavior}

A decrease in $\mathrm{pH}$ due to increased diet fermentability could be compensated by a change in feeding behavior, resulting in more stable rumen conditions, as was shown by Krause et al. (2003). This compensation did not occur in our study as the number of meals, total daily eating time or eating time per meal were not affected by mRDC. Feeding behavior and DMI in lactating dairy cows can be affected by several dietary characteristics such as (forage) NDF content, particle size, or (ruminal degradable) starch content (Allen et al., 2009; Schadt et al., 2012; Ferraretto et al., 2013). Exchanging starch for nonforage fiber sources can result in an increased DMI (Abrahamse et al., 2008; Arndt et al., 2014; Boerman et al., 2015), decreased DMI (Lechartier and Peyraud, 2011), or no DMI response (Dann et al., 2014, 2015). Assuming that rumen fill was not limiting, a decreased NDF intake with increasing $\mathrm{mRDC}$ might be the reason why DMI tended to linearly increase with increasing mRDC.

Eating time, as a component of feeding behavior, can be affected by particle size of ingested feed (mainly forage) because particles need to be masticated to a certain length before they can be swallowed (Schadt et al., 2012). As the forage base in our study was identical between treatments this is not expected to have influenced feeding behavior or DMI. Concentrates in our study were ground at $3 \mathrm{~mm}$ before pelleting so it can be expected that particle size was below the threshold given by Schadt et al. (2012) and that eventual differences between treatments were small, thereby not influencing eating time.

Propionate infused in the rumen of lactating dairy cows has shown different responses on DMI (Raggio et al., 2006; Stocks and Allen, 2012, 2014). Although DMI decreased in the studies of Stocks and Allen (2012, 2014), neither study observed effects on feeding behavior such as number of meals per day, meal duration, or DMI per meal. Propionate production or proportion in the rumen was not determined in our study, but it is likely that differences between treatments were not large enough to exert an effect on feeding behavior or DMI.

\section{Applicability of mRDC in Diet Formulation}

The observed responses to $\mathrm{mRDC}$ in our study, despite the fact that treatments were calculated to be isoenergetic and iso-nitrogenous, indicate that the amount of $\mathrm{mRDC}$ can have additional value next to $\mathrm{NE}_{\mathrm{L}}$ and ME for controlling dairy cow performance. The model proposed for mRDC is relatively simple as compared with more complex rumen models such as Dijkstra et al. (1992). However, the present simple model still uses several fractional degradation and passage rate values. When formulating simple diets, an estimation of rumen degradable starch could lead to similar results as mRDC. However, when diets are more complex with several sources of carbohydrates [e.g., NDF from different feedstuffs (sugar beet pulp or soy hulls vs. forage fiber)] or high-sugar diets, just using degradable starch would not be sufficient. For the use of mRDC in diet formulation, rumen fractional degradation and passage rates, which are already available in feed matrixes, can be used without the need for the user to adapt them. These rates can be fixed values or can be calculated with feedstuff-specific equations that use analyzed proximate nutrients as input, depending on the type of feedstuff or characteristic, as described by Van Duinkerken et al. (2011) and Volden (2011). With this approach, farm-specific feedstuffs only require an 
analysis of the proximate nutrients to drive the model. This analysis can be done by laboratories that have developed NIRS calibrations specifically for this purpose.

\section{CONCLUSIONS}

Increasing dietary levels of $\mathrm{mRDC}$ without changes in other dietary characteristics, which include commonly used feed evaluation values such as $\mathrm{NE}_{\mathrm{L}}$ and DVE, but also mTDC and bypass starch, showed significant effects on FPCM, milk fat and protein yield, and milk protein concentration. No effect on rumen $\mathrm{pH}$ parameter estimates and minor effects on feeding behavior were observed. Our results suggest that aggregating rapidly degradable carbohydrate content into one term mRDC may result in a simple formulation tool to improve predictability of production response in practical diet formulation.

\section{ACKNOWLEDGMENTS}

The authors acknowledge the staff at the dairy research farm Kempenshof (Boxmeer, the Netherlands) and J. Bikker (MS student, Wageningen University \& Research, Wageningen, the Netherlands) for their contribution in the execution of the study and J. Doelman (Trouw Nutrition, Boxmeer, the Netherlands) for correcting the English version of the manuscript. The study was funded by Trouw Nutrition (Boxmeer, the Netherlands).

\section{REFERENCES}

Abrahamse, P. A., B. Vlaeminck, S. Tamminga, and J. Dijkstra. 2008 The effect of silage and concentrate type on intake behavior, rumen function, and milk production in dairy cows in early and late lactation. J. Dairy Sci. 91:4778-4792.

Allen, M. S., B. J. Bradford, and M. Oba. 2009. Board-Invited Review: The hepatic oxidation theory of the control of feed intake and its application to ruminants. J. Anim. Sci. 87:3317-3334.

AOAC International. 2002. AOAC Official Method 2002.04 AmylaseTreated Neutral Detergent Fiber in Feeds. 17th ed. AOAC Int., Gaithersburg, MD

Arndt, C., L. E. Armentano, and M. B. Hall. 2014. Corn bran versus corn grain at 2 levels of forage: Intake, apparent digestibility, and production responses by lactating dairy cows. J. Dairy Sci. 97:5676-5687.

Arriola Apelo, S. I., J. R. Knapp, and M. D. Hanigan. 2014. Invited review: Current representation and future trends of predicting amino acid utilization in the lactating dairy cow. J. Dairy Sci. 97:4000-4017

Bauman, D. E., and J. M. Griinari. 2003. Nutritional regulation of milk fat synthesis. Annu. Rev. Nutr. 23:203-227.

Boerman, J. P., S. B. Potts, M. J. VandeHaar, M. S. Allen, and A. L. Lock. 2015. Milk production responses to a change in dietary starch concentration vary by production level in dairy cattle. J. Dairy Sci. 98:4698-4706.

Cantalapiedra-Hijar, G., S. Lemosquet, J. M. Rodriguez-Lopez, F. Messad, and I. Ortigues-Marty. 2014. Diets rich in starch increase the posthepatic availability of amino acids in dairy cows fed diets at low and normal protein levels. J. Dairy Sci. 97:5151-5166.
Cantalapiedra-Hijar, G., I. Ortigues-Marty, and S. Lemosquet. 2015. Diets rich in starch improve the efficiency of amino acids use by the mammary gland in lactating Jersey cows. J. Dairy Sci. 98:6939-6953.

Colman, E., B. M. Tas, W. Waegeman, B. De Baets, and V. Fievez. 2012. The logistic curve as a tool to describe the daily ruminal $\mathrm{pH}$ pattern and its link with milk fatty acids. J. Dairy Sci. 95:58455865

CVB. 2012. CVB Feed Table 2011. Product Board Animal Feed, the Netherlands.

Daniel, J. B., N. C. Friggens, P. Chapoutot, H. Van Laar, and D. Sauvant. 2016. Milk yield and milk composition responses to change in predicted net energy and metabolizable protein: A meta-analysis. Animal 10:1975-1985.

Dann, H. M., S. M. Fredin, K. W. Cotanch, R. J. Grant, C. Kokko, P. Ji, and K. Fujita. 2015. Effects of corn-based reduced-starch diets using alternative carbohydrate sources on performance of lactating Holstein cows. J. Dairy Sci. 98:4041-4054.

Dann, H. M., H. A. Tucker, K. W. Cotanch, P. D. Krawczel, C. S. Mooney, R. J. Grant, and T. Eguchi. 2014. Evaluation of lower-starch diets for lactating Holstein dairy cows. J. Dairy Sci. 97:7151-7161.

Dijkstra, J., J. L. Ellis, E. Kebreab, A. B. Strathe, S. López, J. France, and A. Bannink. 2012. Ruminal pH regulation and nutritional consequences of low pH. Anim. Feed Sci. Technol. 172:22-33.

Dijkstra, J., H. D. S. C. Neal, D. E. Beever, and J. France. 1992. Simulation of nutrient digestion, absorption and outflow in the rumen Model description. J. Nutr. 122:2239-2256.

EC. 1971. First Commission Directive 71/250/EEC establishing Community methods of analysis for the official control of feedingstuffs. Official Journal L 155:13-37.

EC. 2009. No 152/2009. Commission regulation laying down the methods of sampling and analysis for the official control of feed. Off. J. Eur. Union L 54:1-130.

Fanchone, A., P. Nozière, J. Portelli, B. Duriot, V. Largeau, and M. Doreau. 2013. Effects of nitrogen underfeeding and energy source on nitrogen ruminal metabolism, digestion, and nitrogen partitioning in dairy cows. J. Anim. Sci. 91:895-906.

Ferraretto, L. F., P. M. Crump, and R. D. Shaver. 2013. Effect of cereal grain type and corn grain harvesting and processing methods on intake, digestion, and milk production by dairy cows through a meta-analysis. J. Dairy Sci. 96:533-550.

Huhtanen, P., and J. Nousiainen. 2012. Production responses of lactating dairy cows fed silage-based diets to changes in nutrient supply. Livest. Sci. 148:146-158.

ISO. 2004. Animal feeding stuffs-Enzymatic determination of total starch content. ISO 15914:2004. International Organization for Standardization, Geneva, Switzerland.

ISO. 2006a. Milk-Enumeration of somatic cells-Part 2: Guidance on the operation of fluoro-opto-electronic counters. ISO 133662:2006. International Organization for Standardization, Geneva, Switzerland

ISO. 2006b. Animal feeding stuffs-Determination of amylase-treated neutral detergent fibre content (aNDF). ISO 16472:2006. International Organization for Standardization, Geneva, Switzerland.

ISO. 2008. Food products-Determination of the total nitrogen content by combustion according to the Dumas principle and calculation of the crude protein content-Part 1: Oilseeds and animal feeding stuffs. ISO 16634-1:2008. International Organization for Standardization, Geneva, Switzerland.

ISO. 2012. Animal feeding stuffs - Guidelines for sample preparation ISO 16498:2012. International Organization for Standardization, Geneva, Switzerland

ISO. 2013. Milk and liquid milk products - Guidelines for the application of mid-infrared spectrometry. ISO/DIS 9622:2013. International Organization for Standardization, Geneva, Switzerland.

Krause, K. M., D. K. Combs, and K. A. Beauchemin. 2003. Effects of increasing levels of refined cornstarch in the diet of lactating dairy cows on performance and ruminal pH. J. Dairy Sci. 86:1341-1353.

Lechartier, C., and J. L. Peyraud. 2011. The effects of starch and rapidly degradable dry matter from concentrate on ruminal digestion 
in dairy cows fed corn silage-based diets with fixed forage proportion. J. Dairy Sci. 94:2440-2454.

Nozière, P., F. Glasser, and D. Sauvant. 2011. In vivo production and molar percentages of volatile fatty acids in the rumen: A quantitative review by an empirical approach. Animal 5:403-414.

NRC. 2001. Nutrient Requirements of Dairy Cattle. 7th rev. ed. National Academy Press, Washington, DC.

Ørskov, E. R., and I. McDonald. 1979. The estimation of protein degradability in the rumen from incubation measurements weighted according to rate of passage. J. Agric. Sci. (Camb.) 92:499-503.

Piccioli-Cappelli, F., J. J. Loor, C. J. Seal, A. Minuti, and E. Trevisi. 2014. Effect of dietary starch level and high rumen-undegradable protein on endocrine-metabolic status, milk yield, and milk composition in dairy cows during early and late lactation. J. Dairy Sci. 97:7788-7803.

Raggio, G., G. E. Lobley, S. Lemosquet, H. Rulquin, and H. Lapierre. 2006. Effect of casein and propionate supply on whole body protein metabolism in lactating dairy cows. Can. J. Anim. Sci. $86: 81-89$

Rigout, S., C. Hurtaud, S. Lemosquet, A. Bach, and H. Rulquin. 2003. Lactational effect of propionic acid and duodenal glucose in cows. J. Dairy Sci. 86:243-253.

Schadt, I., J. D. Ferguson, G. Azzaro, R. Petriglieri, M. Caccamo, P. Van Soest, and G. Licitra. 2012. How do dairy cows chew?-Particle size analysis of selected feeds with different particle length distributions and of respective ingested bolus particles. J. Dairy Sci. 95:4707-4720.

Stocks, S. E., and M. S. Allen. 2012. Hypophagic effects of propionate increase with elevated hepatic acetyl coenzyme A concentration for cows in the early postpartum period. J. Dairy Sci. 95:3259-3268.

Stocks, S. E., and M. S. Allen. 2014. Effects of lipid and propionic acid infusions on feed intake of lactating dairy cows. J. Dairy Sci. 97:2297-2304.

Sutton, J. D., M. S. Dhanoa, S. V. Morant, J. France, D. J. Napper, and E. Schuller. 2003. Rates of production of acetate, propionate, and butyrate in the rumen of lactating dairy cows given normal and low-roughage diets. J. Dairy Sci. 86:3620-3633.

Tamminga, S., W. M. Van Straalen, A. P. J. Subnel, R. G. M. Meijer, A. Steg, C. J. G. Wever, and M. C. Blok. 1994. The Dutch protein evaluation system: The DVE/OEB-system. Livest. Prod. Sci. 40:139-155.

Thomas, P. C., and P. A. Martin. 1988. The influence of nutrient balance on milk yield and composition. Pages $97-118$ in Nutrition and Lactation in the Dairy Cow. P. C. Garnsworthy, ed. Butterworths, London, UK.

Tilley, J. M. A., and R. A. Terry. 1963. A two-stage technique for the in vitro digestion of forage crops. Grass Forage Sci. 18:104-111.

Tylutki, T. P., D. G. Fox, V. M. Durbal, L. O. Tedeschi, J. B. Russell, M. E. Van Amburgh, T. R. Overton, L. E. Chase, and A. N. Pell. 2008. Cornell Net Carbohydrate and Protein System: A model for precision feeding of dairy cattle. Anim. Feed Sci. Technol. 143:174-202.

Van Duinkerken, G., M. C. Blok, A. Bannink, J. W. Cone, J. Dijkstra, A. M. Van Vuuren, and S. Tamminga. 2011. Update of the Dutch protein evaluation system for ruminants: The DVE/OEB2010 system. J. Agric. Sci. 149:351-367.

Van Es, A. J. H. 1978. Feed evaluation for ruminants. I. The systems in use from May 1977 onwards in The Netherlands. Livest. Prod. Sci. 5:331-345.

Van Laar, H., and J. Doorenbos. 2014. Within laboratory repeatability of the in situ nylon bag method. J. Dairy Sci. 97 (E-Suppl. 1):798 (Abstr.)

Volden, H. 2011. NorFor-The Nordic feed evaluation system. EAAP publication No. 130. Wageningen Academic Publishers, Wageningen, the Netherlands.

Yeates, M. P., B. J. Tolkamp, D. J. Allcroft, and I. Kyriazakis. 2001. The use of mixed distribution models to determine bout criteria for analysis of animal behaviour. J. Theor. Biol. 213:413-425.

\section{APPENDIX}

Table A1. For the calculation of modeled rapidly degradable carbohydrates, the contribution of rapidly degradable material per nutrient was calculated using fractional degradation and passage rates according to Van Duinkerken et al. (2011)

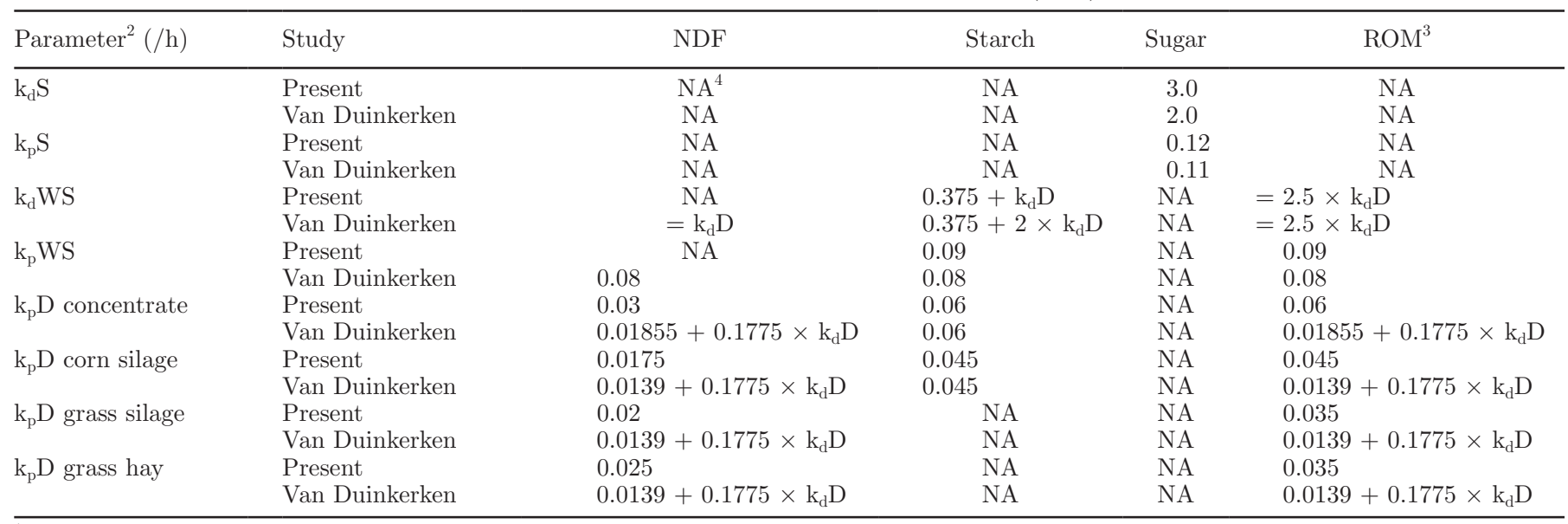

${ }^{1}$ Minor modifications to some of these values have been made, and for comparison fractional rates used in the present study as well as fractional rates used by Van Duinkerken et al. (2011) are presented.

${ }^{2} \mathrm{~S}=$ soluble fraction; WS $=$ washable - soluble fraction; $\mathrm{D}=$ nonwashable, potentially degradable fraction; $\mathrm{k}_{\mathrm{d}}=$ fractional degradation rate; $\mathrm{k}_{\mathrm{p}}=$ fractional passage rate.

${ }^{3}$ Residual OM [DM minus ash, CP, NDF, starch, sugar, crude fat, and fermentation acids (in silages only)].

${ }^{4} \mathrm{NA}=$ not applicable. 